\title{
INTRA- AND INTEROBSERVER ANALYSIS OF PEDICLE SCREW PLACEMENT IN SCOLIOSIS CORRECTION
}

\author{
ANÁLISE INTRA E INTEROBSERVADOR DE POSICIONAMENTO DE PARAFUSOS \\ PEDICULARES EM CORREÇÃO DE ESCOLIOSE
}

\section{ANÁLISIS INTRA E INTEROBSERVADOR DE POSICIONAMIENTO DE TORNILLOS PEDICULARES EN CORRECCIÓN DE ESCOLIOSIS}

\author{
Caíleue Jauhar de Castro, ${ }^{1}$ Luis Eduardo Carelli Teixeira da Silva, ${ }^{1,2,3}$ Luiz Eduardo Almeida, ${ }^{1,2}$ Alderico Girão Campos de Barros, ${ }^{1}$ Robson Teixeira Vital, 13 \\ Márcia Maria Rodrigues Jardim, ${ }^{3}$ Giuliana Vasconcelos de Souza Fonseca 4 \\ 1. Instituto Nacional de Traumatologia e Ortopedia (INTO), Rio de Janeiro, RJ, Brazil. \\ 2. Instituto da Coluna Vertebral do Rio de Janeiro (INCOL), Rio de Janeiro, RJ, Brazil. \\ 3. Universidade Federal do Estado do Rio de Janeiro, Graduate Program in Neurology (PPGNEURO- UNIRIO), Rio de Janeiro, RJ, Brazil. \\ 4. Instituto de Pesquisas Biomédicas do Hospital Naval Marcílio Dias (IPB HNMD), Rio de Janeiro, RJ, Brazil.
}

\begin{abstract}
Objective: To establish the statistical interobserver and intraobserver concordance of thoracic pedicle screw placement in scoliosis surgery, with a 4-week interval between the two analyses. Methods: Of 55 patients that evaluated the intra- and interobserver concordances of the screw positions (according to the Abul-Kasim classification) using the Kappa coefficient. Results: The intraobserver concordance ranged from a Kappa coefficient of 0.516 to 0.889 ("moderate" to "almost perfect") between the two analyses performed four weeks apart. Interobserver concordance ranged from 0.379 to 0.633 ("reasonable" to "strong"). Conclusion: The intraobserver concordance was always greater than the interobserver concordance. No concordance coefficient was classified as "insignificant" or "weak". Level of Evidence III; Retrospective study.
\end{abstract}

Keywords: Scoliosis; Pedicle Screws; Spine Deformity.

\section{RESUMO}

Objetivo: Estabelecer a concordância estatística interobservadores e intraobservadores do posicionamento de parafusos pediculares torácicos em cirurgia de escoliose, com intervalo de quatro semanas entre as duas análises. Métodos: Com 55 pacientes, que avalia as concordâncias intra e interobservador da posição dos parafusos (segundo a classificação de Abul-Kasim), utilizando o coeficiente de Kappa. Resultados: A concordância intraobservador variou entre 0,516 e 0,889 ("moderada" a "quase perfeita") de coeficiente Kappa, entre análises com intervalo de quatro semanas. A concordância interobservador variou entre 0,379 e 0,633 ("razoável" a "forte"). Conclusões: A concordância intraobservador foi sempre maior que a interobservador. Nenhum coeficiente de concordância foi classificado como "insuficiente" ou "fraco". Nível de Evidência III; Estudo retrospectivo.

Descritores: Escoliose; Parafusos Pediculares; Deformidade da Coluna.

\section{RESUMEN}

Objetivo: Establecer la concordancia estadística interobservadores e intraobservadores del posicionamiento de tornillos pediculares torácicos en cirugía de escoliosis, con intervalo de cuatro semanas entre los dos análisis. Métodos: Estudio de cohorte retrospectivo (nivel con 55 pacientes, que evalúa las concordancias intra e interobsenvador de la posición de los tornillos (según la clasificación de Abul-Kasim), usando el coeficiente de Kappa. Resultados: La concordancia intraobservador varió entre 0,516 y 0,889 ("moderada" a "casi perfecta"), de coeficiente Kappa, entre análisis con intervalo por 4 semanas. La concordancia interobservador varió entre 0,379 y 0,633 ("razonable" a "fuerte"). Conclusiones: La concordancia intraobservador fue siempre mayor que la interobservador. Ningún coeficiente de concordancia fue clasificado como "insuficiente" o "débil". Nivel de Evidencia III; Estudio retrospectivo.

Descriptores: Escoliosis; Tornillos Pediculares; Deformidad de la Columna.

\section{INTRODUCTION}

Spinal deformities are defined as changes in the axis of the coronal planes or the physiological curvatures that make up sagittal alignment. Within this group of diseases, the scoliosis group stands out from an epidemiological perspective with varied etiology and with initially conservative treatment, which often evolves to require surgical intervention. ${ }^{1-3}$
Many surgical procedures have been described since the middle of the 20th century, from arthrodesis without instrumentation with the Risser jacket, ${ }^{4}$ evolving to Harrington rods in $1962,{ }^{5}$ to the use of sublaminar wires and hooks by Luque ${ }^{6}$ and Allen-Fergunson ${ }^{7}$, up to the latest techniques using pedicle screws.

First described by Roy-Camille, ${ }^{8}$ and connected to plates for 
strictly lumbar diseases, these screws were improved and targeted towards the correction of scoliosis by authors such as Suk. ${ }^{9}$

The use of pedicle screws for the surgical treatment of spinal deformities has been considered the gold standard for years, when compared to the old fixation methods such as wires and hooks. Its potential for three-dimensional correction, maintaining correction and sparing levels from arthrodesis has made it popular. ${ }^{10,11}$

With this advent, the safety of insertion became one of the primary concerns and many detailed studies were published, confirming safety, first in the lumbar vertebrae and later in the thoracic vertebrae of patients with scoliotic deformities. ${ }^{10-13}$ Some case series reported the risk of malpositioning of implants in the thoracic spine of patients with scoliosis to be between 1.5 and $43 \%,{ }^{14,15}$ however, with a low rate of neurological repercussion, between 0 and $0.9 \%{ }^{16-20}$

To verify the positioning of the implants, we used postoperative tomographic control in axial cuts to permit the use of the Abul-Kasim ${ }^{21}$ classification (Figure 1) to evaluate the screw-pedicle relationship, allowing them to be classified both in a position considered "normal" and in a poor position, "lateral" or "medial", to the cortex limits of the pedicles.

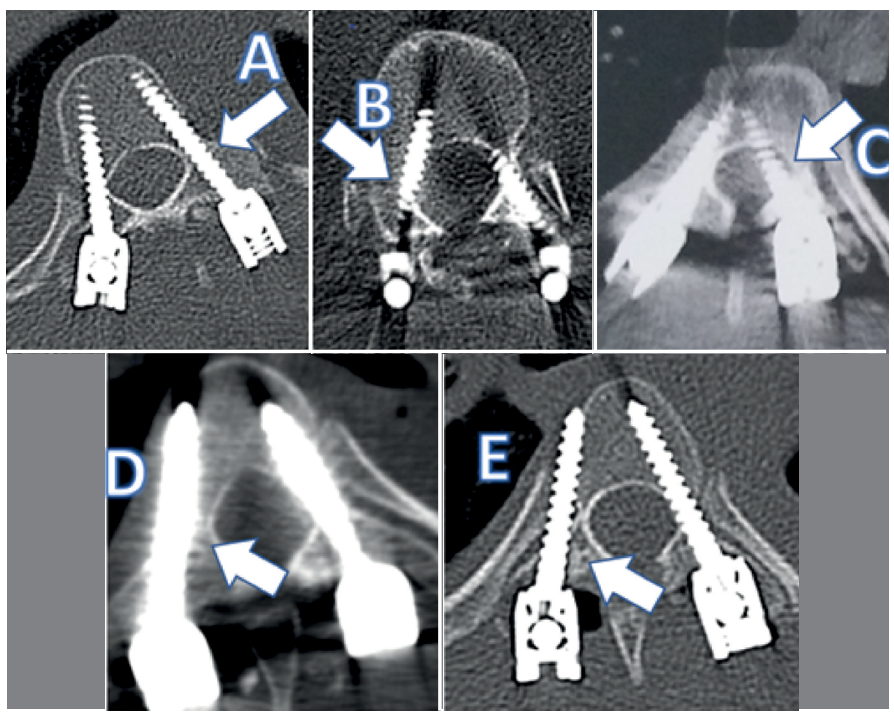

Figure 1. Abul-Kasim Classification: A) Correct pedicle screw positioning. In the axial view it remains confined to the pedicle walls and in the sagittal reconstruction it does not perforate the upper terminal plate or the intervertebral foramen. B) Grade I medial cortical perforation of the pedicle, with more than $1 / 2$ of the screw medial to the medial cortex of the pedicle. C) Grade II medial cortical perforation of the pedicle, with the screw totally medial to the medial cortex of the pedicle. D) Grade I lateral cortical perforation of the pedicle, with more than $1 / 2$ of the screw lateral to the lateral cortex of the pedicle. E) Grade II lateral cortical perforation of the pedicle, with the screw totally lateral to the lateral cortex of the pedicle.

\section{METHODS}

This was a retrospective, observational cohort study of 55 patients who underwent posterior approach surgical treatment for scoliosis using pedicle screws in two institutions (but with the same team of surgeons) between 2016 and 2019.

In total, 47 patients were diagnosed with idiopathic scoliosis, four with congenital scoliosis, one with neuromuscular scoliosis and three with syndromic scoliosis. They ranged in age from 10 to 50 years, 11 of them being male and 44 female. The curves ranged from 41 to 120 degrees as measured using the Cobb method.

A sample of 810 screws, inserted in a total of 55 patients, using the free-hand technique or with the assistance of an image intensifier, was obtained so there would be a significant statistical value that would also correspond as faithfully as possible to reality.
The same team of surgeons was responsible for all the screw insertions, as well as the curve correction maneuvers.

The surgeries were performed by posterior longitudinal access followed by the detachment of the subperiosteal muscle from the levels necessary for the correction. Pedicular instrumentation was performed using the free-hand technique or with radioscopic assistance when necessary. The diameter of the titanium pedicle screws varied between 4.0 and $6.5 \mathrm{~mm}$.

The evaluation of the positioning of these implants used postoperative tomography and was performed by three orthopedists with a minimum of two years of training in spinal deformity surgeries. The Abul-Kasim classification was taken as the reference for establishing both the ideal positioning and to grade the implantation errors. All the screws were analyzed by the three observers on two separate occasions four weeks apart.

The analysis of screw position in relation to the pedicles was performed with the classifications "NORMAL"(N), "GRADE I MEDIAL PERFORATION" (M1), "GRADE II MEDIAL PERFORATION" (M2), GRADE I LATERAL PERFORATION" (L1) and "GRADE II LATERAL PERFORATION" (L2) by the three observing surgeons, according to the Abul-Kasim description. ${ }^{21}$ (Figure 1) The tomographies analyzed for this classification were found in the digital patient record archives and are routinely performed postoperatively following scoliosis correction surgery as a form of standard of care, ${ }^{22}$ given the fact that not only erratic insertion may occur, but also displacement of the derotation (for scoliotic correction) during the surgery that can lead the phenomenon of plowing with concomitant damage to one of the cortical walls of the pedicle. ${ }^{23,24}$ The thoracic pedicles were identified in the axial plane in their isthmus and the images were separated and organized in a PowerPoint presentation for better evaluation by the observers.

The results were statistically analyzed with degree of concordance evaluated by the kappa with quadratic weights method (Fleiss-Cohen). ${ }^{25-29}$ This coefficient is stipulated to describe the concordance between two or more observers when a nominal or ordinal evaluation of the same sample is performed. For this method, values less than zero are considered insignificant; from zero to 0.2 as weak; from 0.21 to 0.4 as reasonable; from 0.4 to 0.6 as moderate; from 0.6 to 0.8 as strong and greater than 0.8 as almost perfect, as shown in Table 1.

This study was approved by the Institutional Review Board of the service responsible (INTO) as CAAE number 70885517.4.00005273 and included in the Plataforma Brasil. The use of the Informed Consent Form for the patients was waived because the study used information already contained in the digital archives of the Institute, being replaced by the Term of Responsibility and the ethics of the examiner.

Table 1. Interpretation of Cohen's kappa coefficient of concordance.

\begin{tabular}{c|c}
\hline Kappa Value & Interpretation \\
\hline Less than zero & Insignificant (poor) \\
\hline Between 0 and 0.2 & Weak (slight) \\
\hline Between 0.21 and 0.4 & Reasonable (fair) \\
\hline Between 0.41 and 0.6 & Moderate (moderate) \\
\hline Between 0.61 and 0.8 & Strong (substantial) \\
\hline Between 0.81 and 1 & Almost perfect (almost perfect) \\
\hline
\end{tabular}

\section{RESULTS}

Tables 2 and 3 provide the frequency (n) and the percentage (\%) of the Abul-Kasim classification of the placement of concave and convex pedicle screws, respectively, in the two evaluations by the three observers. In some cases, the observers classified the image as inconclusive and these were not considered in the analysis.

Tables 4 and 5 show the concordance observed (in \%), the Kappa statistic and the descriptive level ( $p$-value) for each pair compared, by intra- and interobserver, respectively. The concordance 
Table 2. Abul-Kasim classifications of screw placement in concave pedicles.

\begin{tabular}{c|c|c|c|c|c|c|c|c|c|c|c|c}
\hline Evaluation & \multicolumn{9}{|c|}{ First } & \multicolumn{5}{c|}{ Second } \\
\hline Observer & \multicolumn{2}{|c|}{} & \multicolumn{2}{|c|}{$\mathbf{2}$} & \multicolumn{2}{|c|}{$\mathbf{3}$} & \multicolumn{2}{|c|}{} & \multicolumn{2}{|c|}{} & \multicolumn{2}{|c}{$\mathbf{3}$} \\
\hline Classification & $\mathbf{n}$ & $\%$ & $\mathbf{n}$ & $\%$ & $\mathbf{n}$ & $\%$ & $\mathbf{N}$ & $\%$ & $\mathbf{N}$ & $\%$ & $\mathbf{n}$ & $\%$ \\
\hline L2 & 11 & 2.8 & 12 & 3.1 & 13 & 3.3 & 13 & 3.3 & 22 & 5.6 & 8 & 2.0 \\
\hline $\mathrm{L} 1$ & 19 & 4.9 & 15 & 3.8 & 15 & 3.8 & 17 & 4.3 & 15 & 3.8 & 20 & 5.1 \\
\hline Normal & 332 & 85.6 & 312 & 79.8 & 329 & 83.3 & 329 & 84.1 & 305 & 78.2 & 335 & 85.7 \\
\hline $\mathrm{M} 1$ & 23 & 5.9 & 38 & 9.7 & 30 & 7.6 & 23 & 5.9 & 38 & 9.7 & 27 & 6.9 \\
\hline $\mathrm{M} 2$ & 3 & 0.8 & 14 & 3.6 & 8 & 2.0 & 9 & 2.3 & 10 & 2.6 & 1 & 0.3 \\
\hline
\end{tabular}

M1: Abul-Kasim grade I medial perforation; M2: grade II medial perforation; L1: grade I lateral perforation; grade II lateral perforation.

Table 3. Abul-Kasim classifications of screw placement in convex pedicles.

\begin{tabular}{c|c|c|c|c|c|c|c|c|c|c|c|c}
\hline Evaluation & \multicolumn{9}{|c|}{ First } & \multicolumn{6}{c|}{ Second } \\
\hline Observer & \multicolumn{2}{|c|}{$\mathbf{1}$} & \multicolumn{2}{|c|}{$\mathbf{2}$} & \multicolumn{2}{|c|}{$\mathbf{3}$} & \multicolumn{3}{|c|}{$\mathbf{2}$} & \multicolumn{2}{|c}{$\mathbf{3}$} \\
\hline Classification & $\mathbf{n}$ & $\%$ & $\mathbf{n}$ & $\%$ & $\mathbf{n}$ & $\%$ & $\mathbf{N}$ & $\%$ & $\mathbf{N}$ & $\%$ & $\mathbf{N}$ & $\%$ \\
\hline L2 & 15 & 3.6 & 29 & 7.0 & 14 & 3.4 & 16 & 3.8 & 18 & 4.3 & 11 & 2.7 \\
\hline L1 & 20 & 4.8 & 20 & 4.8 & 17 & 4.1 & 18 & 4.3 & 28 & 6.7 & 16 & 3.9 \\
\hline Normal & 337 & 80.8 & 329 & 79.5 & 360 & 86.7 & 361 & 86.4 & 332 & 79.4 & 364 & 89.0 \\
\hline M1 & 36 & 8.6 & 26 & 6.3 & 20 & 4.8 & 20 & 4.8 & 38 & 9.1 & 15 & 3.7 \\
\hline M2 & 9 & 2.2 & 10 & 2.4 & 4 & 1.0 & 3 & 0.7 & 2 & 0.5 & 3 & 0.7 \\
\hline
\end{tabular}

M1: Abul-Kasim grade I medial perforation; M2: grade II medial perforation; L1: grade I lateral perforation; grade II lateral perforation.

Table 4. Intraobserver analysis of pedicle screw placement by the AbulKasim classification.

\begin{tabular}{|c|c|c|c|c|c|c|}
\hline Evaluation & Observer & Pedicle & $\mathbf{N}$ & \begin{tabular}{|l|} 
Concordance \\
observed (\%)
\end{tabular} & $\begin{array}{c}\text { Kappa } \\
\text { Coefficient }\end{array}$ & $p$-value \\
\hline \multirow{6}{*}{$\begin{array}{c}\text { First } \\
\text { evaluation } \\
x \\
\text { Second } \\
\text { evaluation }\end{array}$} & \multirow{2}{*}{1} & Concave & 382 & 89.5 & 0.611 & $<0.0001$ \\
\hline & & Convex & 411 & 85.6 & 0.516 & $<0.0001$ \\
\hline & \multirow{2}{*}{2} & Concave & 379 & 85.0 & 0.591 & $<0.0001$ \\
\hline & & Convex & 402 & 86.6 & 0.627 & $<0.0001$ \\
\hline & \multirow{2}{*}{3} & Concave & 390 & 93.8 & 0.777 & $<0.0001$ \\
\hline & & Convex & 409 & 97.6 & 0.889 & $<0.0001$ \\
\hline
\end{tabular}

Table 5. Interobserver analysis of pedicle screw placement by the AbulKasim classification.

\begin{tabular}{|c|c|c|c|c|c|c|}
\hline Evaluation & Observer & Pedicle & $\mathbf{N}$ & \begin{tabular}{|l}
$\begin{array}{l}\text { Concordance } \\
\text { observed (\%) }\end{array}$ \\
\end{tabular} & \begin{tabular}{c|} 
Kappa \\
Coefficient
\end{tabular} & $p$-value \\
\hline \multirow{6}{*}{$\begin{array}{c}\text { First } \\
\text { evaluation }\end{array}$} & Obs $1 \times$ Obs2 & \multirow{3}{*}{ Concave } & 379 & 84.7 & 0.512 & $<0.0001$ \\
\hline & Obs $1 \times$ Obs3 & & 378 & 86.2 & 0.506 & $<0.0001$ \\
\hline & Obs $2 \times$ Obs 3 & & 380 & 86.3 & 0.578 & $<0.0001$ \\
\hline & Obs1 1 Obs2 & \multirow{3}{*}{ Convex } & 403 & 83.6 & 0.535 & $<0.0001$ \\
\hline & Obs $1 \times$ Obs3 & & 403 & 83.4 & 0.434 & $<0.0001$ \\
\hline & Obs $2 \times$ Obs 3 & & 403 & 84.1 & 0.465 & $<0.0001$ \\
\hline \multirow{6}{*}{$\begin{array}{l}\text { Second } \\
\text { evaluation }\end{array}$} & Obs $1 \times$ Obs 2 & \multirow{3}{*}{ Concave } & 386 & 87.8 & 0.633 & $<0.0001$ \\
\hline & Obs $1 \times$ Obs3 & & 376 & 87.2 & 0.517 & $<0.0001$ \\
\hline & Obs $2 \times$ Obs 3 & & 377 & 83.0 & 0.466 & $<0.0001$ \\
\hline & Obs $1 \times$ Obs2 & \multirow{3}{*}{ Convex } & 413 & 87.9 & 0.607 & $<0.0001$ \\
\hline & Obs1 1 Obs3 & & 397 & 85.6 & 0.379 & $<0.0001$ \\
\hline & Obs $2 \times$ Obs 3 & & 400 & 82.0 & 0.382 & $<0.0001$ \\
\hline
\end{tabular}

observed corresponds to the percentage (\%) of identical responses for the total number of images available. For example, of the total of 379 pedicles, observer 1 agreed with observer 2 in $84.7 \%$ of cases, according to the Abul-Kasim classification.

The intraobserver analysis showed that there was not absolute concordance for the researchers between the first and second evaluations.

The first evaluator presented strong concordance (between 0.61 and 0.8 ) and moderate concordance (between 0.41 and 0.6), for concave and convex pedicles, respectively. The concordance of the second evaluator was classified as moderate (between 0.41 and 0.6) for concave pedicles and strong (between 0.61 and 0.8 ) for convex pedicles. The third evaluator had the highest concordance, classified as strong (between 0.61 and 0.8 ) for concave pedicles and almost perfect (between 0.81 and 1) for convex pedicles.

The interobserver analysis showed that there was not absolute concordance among the researchers in relation to the Abul-Kasim classification. The interobserver kappa ranged from 0.379 to 0.633 , with reasonable, moderate, and strong combinations.

In the first evaluation, all observers were moderately concordant both for concave and convex pedicles. In the second evaluation, observers 1 and 2 were the most concordant, with strong concordance (0.633 for concave and 0.607 for convex pedicle screws). In the second evaluation, observer 3 was moderately concordant for concave and reasonably concordant for convex pedicle screws, these being the lowest concordances observed.

\section{DISCUSSION}

The safety of screw insertion in scoliosis correction surgery has always been one of the major concerns of surgeons because of the potential and serious complications that erratic insertion can cause. Initially, studies at lumbar levels and later at thoracic levels showed the safety of using these implants. ${ }^{10-12}$

Transpedicular instrumentation in the thoracic spine is more difficult technically than in the lumbar levels due to the narrowing of the pedicles and the less accurate intraoperative fluoroscopic evaluation. ${ }^{13}$

There are several techniques for the insertion of pedicle screws into the thoracic spine, which can be performed using the free-hand technique, with the assistance of the fluoroscope or navigation. ${ }^{14}$

Thoracic pedicles have a smaller diameter and patients with scoliosis are more prone to anatomical changes of the pedicular morphology, increasing the risk of cortical perforation and malpositioning of the implant, which can range from 1.5 to $43 \%$ in some series. ${ }^{14,15}$ Despite this, neurological complication rates vary between 0 and $0.9 \%{ }^{16-20}$

The anatomical morphology of the pedicles analyzed preoperatively by radiographs and computed tomography and intraoperatively by fluoroscopy can be used to predict the ease and safety of transpedicular instrumentation. , $^{5,6}$

Regarding pedicle screw insertion, there is a fear of neurological damage when the medial cortex of the pedicle is violated. However, minor violations are usually asymptomatic if within the "safe zone" of up to $2 \mathrm{~mm}$, as described by Kim and Lenke. A "probably safe zone" is defined between 2 and $4 \mathrm{~mm}$ and a "zone of questionable safety" between 4 and $8 \mathrm{~mm}^{14}$

When it is a matter of erratic positioning with lateral perforation, the risks are lower, varying from small pleural lacerations to cases with devastating consequences, such as serious vascular lesions. ${ }^{30}$

There are also historical classifications, such as that of $\mathrm{Xu},{ }^{31}$ which described the grading of monoaxial pedicle screw insertion errors in the thoracic spines of cadavers, classifying by direct exposure. More recently, other authors have classified implant positions, relating them directly to neurological and vascular complications. ${ }^{32}$ In cases of vertebral fractures in the thoracic spine requiring surgical instrumentation, Zdichavsky et al. described screw positioning not only in relation to the pedicles, but also those that followed an "outside-in" path, achieving some fixation directly to the vertebral body. ${ }^{33}$

To check the positioning of the implants, we used postoperative tomographic control in axial cuts that allowed us to use the Abul-Kasim classification (Figure 1) to evaluate the screw-pedicle relationship.

This classification was chosen for its practicality of not using measurements in millimeters, but only in relation to the central axis of the pedicle and its entire thickness in comparison to the medial and lateral cortical walls of the pedicle. For "CORRECT" positioning, the screw must be inserted entirely within the limits of the pedicle walls or with less than $1 / 2$ of its thickness having violated one of the cortices. When more than $1 / 2$ of its thickness has violated the medial or lateral cortex, we classify it as "GRADE I MEDIAL PERFORATION" (M1) or "GRADE I LATERAL PERFORATION" (L1), respectively. When the entire thickness of the screw violates the medial or lateral cortex, we classify it as "GRADE II MEDIAL PERFORATION" (M2) or "GRADE II LATERAL PERFORATION" (L2), respectively. ${ }^{21}$ 
The Abul-Kasim classification also addresses anterior perforations of the vertebral body and perforations in the sagittal plane (inferior and superior pedicular perforations). The former were not taken into account in this article because they often reflect the surgeon's choice for a bicortical fixation, advancing the thread little by little beyond the cortical wall, and therefore not representing a technical error (in addition, no complications were investigated or revised as a result of the perforations in question). The latter were not measured because of less clinical risk to the patient and the weaker interobserver concordance in the description of the original article.

The rate of malpositioning is described by percentages and varies greatly among the different classical studies, ranging from $1.5 \%$ up to $43 \%{ }^{14,15}$ This rate, as evaluated by the observers in this study, ranged from $11 \%$ to $21.8 \%$, values within the mean ranges of more current works, which report more concordant numbers with a scale of variation ranging from $11.1 \%$ to $13.7 \%$. $^{34-36}$

\section{CONCLUSION}

The rate of malpositioning in all the evaluations was compatible with current studies that evaluated postoperative control tomography to define it, as we did in this study.

This study observed differences between intra- and interobserver concordance in the positional evaluation of the pedicular implants. The intraobserver concordance reached a Kappa coefficient of 0.88 (almost perfect) for one of the observers, but in most of the interobserver comparisons, it was between 0.4 and 0.8 , i.e., classified between moderate and strong. The worst concordance level among the observers presented a Kappa coefficient of 0.379, classified as reasonable. No result (either intra- or interobserver) was considered insignificant or weak.

All authors declare no potential conflict of interest related to this article.

CONTRIBUTION OF THE AUTHORS: Each author made significant individual contributions to this manuscript. CJC: writing, data analysis, review and performance of surgeries; LECTS: surgeries, data analysis and writing; LEA: statistical analysis, surgeries and review; AGCB: performance of surgeries and review; RTV: writing, review and intellectual concept; MMRJ: writing, intellectual concept; GVSF: statistical analysis, review.

\section{REFEREENCES}

1. Aldebeyan S, Sinno H, Makhdom A, Ouellet JA, Saran N. The Impact of Living With Scoliosis: A Utility Outcome Score Assessment. Spine (Phila Pa 1976). 2017;42(2):E93-7.

2. Yoshihara H. Surgical Treatment of Lenke Type 5 Adolescent Idiopathic Scoliosis: A Systematic Review. Spine (Phila Pa 1976). 2019:44(13):E788-99.

3. Agabegi SS, Kazemi N, Sturm PF, Mehlman CT. Natural history of adolescent idiopathic scoliosis in skeletally mature patients: a critical review. J Am Acad Orthop Surg. 2015;23(12):714-23.

4. Risser JC. Scoliosis treated by cast correction and spine fusion. Clin Orthop Relat Res. 1976:(116):86-94.

5. Harrington PR. Treatment of scoliosis: correction and inter- nal fixation by spine instrumentation. J Bone Joint Surg Am. 1962;44-A:591-610.

6. Luque ER. Segmental spinal instrumentation for correction of scoliosis. Clin Orthop Relat Res. 1982:(163):192-8.

7. Allen BL, Ferguson RL. The Galveston experience with L-rod instrumentation for adolescent idiopathic scoliosis. Clin Orthop Relat Res. 1988;(229):59-69.

8. Roy-Camille $\underline{R}$, Saillant G, Mazel C. Internal fixation of the lumbar spine with pedicle screw plating. Clin Orthop Relat Res. 1986:(203):7-17.

9. Suk SI, Lee CK, Kim WJ, Chung YJ, Park YB. Segmental pedicle screw fixation in the treatment of thoracic idiopathic scoliosis. Spine (Phila Pa 1976). 1995;20(12):1399-405.

10. Hamill CL, Lenke LG, Bridwell KH, Chapman MP, Blanke K, Baldus C. The use of pedicle screw fixation to improve correction in the lumbar spine of patients with idiopathic scoliosis. Is it warranted? Spine (Phila Pa 1976). 1996;21(10):1241-9.

11. Liljenqvist UR, Halm HF, Link TM. Pedicle screw instrumentation of the thoracic spine in idiopathic scoliosis. Spine (Phila Pa 1976). 1997;22(19):2239-45.

12. Brown CA, Lenke LG, Bridwell KH, Geideman WM, Hasan SA, Blanke K. Complications of pediatric thoracolumbar and lumbar pedicle screws. Spine (Phila Pa 1976). 1998:23(14):1566-71.

13. Holland NR. Neurophysiological Assessment of Thoracic and Cervical Pedicle Screw Integrity. J Clin Neurophysiol. 2012;29(6):489-92

14. Kim YJ, Lenke LG, Bridwell KH, Cho YS, Riew KD. Free hand pedicle screw placement in the thoracic spine: is it safe? Spine (Phila Pa 1976). 2004;29(3):333-42

15. Belmont PJ, Klemme WR, Robinson M, Polly DH Jr. Accuracy of thoracic pedicle screws in patients with and without coronal plane spinal deformities. Spine (Phila Pa 1976). 2002;27(14):1558-66.

16. Liljenqvist UR, Link TM, Halm HF. Morphometric analysis of thoracic and lumbar vertebrae in idiopathic scoliosis. Spine (Phila Pa 1976) 2000 25:1247-1253. PMID: 10806501.

17. Brown CA, Lenke LG, Bridwell KH, Geideman WM, Hasan SA, Blanke K. Complications of pediatric thoraco-lumbar and lumbar pedicle screws. Spine (Phila Pa 1976).1998:23(14):1566-71.

18. Esses SI, Sachs BL, Dreyzin V. Complications associated with the technique of pedicle screw fixation: a selected survey of ABS members. Spine (Phila Pa 1976). 1993:18(15):2231-8.

19. Lonstein JE, Denis F, Perra JH, Pinto MR, Smith MD, Winter RB. Complications associated with pedicle screws. J Bone Joint Surg Am. 1999;81(11):1519-28.

20. Suk SI, Kim WJ, Lee SM, Kim JH, Chung ER. Thoracic pedicle screw fixation in spinal defor- mities: are they really safe? Spine (Phila Pa 1976). 2001;26(18):2049-57.

21. Abul-Kasim K, Strömbeck A, Ohlin A, Maly P. Sundgren PC. Reliability of low-radiation dose $\mathrm{CT}$ in the assessment of screw placement after posterior scoliosis surgery, evaluated with a new grading system. Spine (Phila Pa 1976). 2009;34(9):941-8

22. Samdani AF, Tantorski M, Cahill PJ, Ranade A, Koch S, Clements DH, et al. Triggered electromyography for placement of thoracic pedicle screws: is it reliable? Eur Spine J. 2011:20(6):869-74

23. Wagner MR, Flores JB, Sanpera I, Herrera-Sot J. Aortic Abutment After Direct Vertebral Rotation. Spine (Phila Pa 1976). 2011:36(3):243-7

24. Essig DA, Miller CP, Xiao M, Ivancic $P$, Jegede $K$, Badrinath $R$, et al. Biomechanical comparison of endplate forces generated by uniaxial screws and monoaxial pedicle screws. Orthopedics. 2012;35(10):e1528-32.

25. Sim J, Wright CC. The kappa statistic in reliability studies: use, interpretation, and sample size requirements. Phys Ther. 2005;85(3):257-68.

26. Barros FS, Perez JMG, Zandonade E, Salles-Cunha SX, Monedero JL. Hilel ABS, et al. Evaluation of pelvic varicose veins using color Doppler ultrasound: comparison of results obtained with ultrasound of the lower limbs, transvaginal ultrasound, and phlebography. J Vasc Bras. 2010;9(2):15-23.

27. Fleiss JL, Cohen J. The equivalence of weighted kappa and the intraclass correlation coefficient as measures of reliability. Educ Psychol Meas. 1973;33(3):613-9.

28. Commenges $D$, Jacqmin $H$. The intraclass correlation coefficient: distribution-free definition and test. Biometrics. 1994;50(2):517-26.

29. Landis JR, Koch GG. The measurement of observer agreement for categorical data. Biometrics. 1977;33(1):159-74.

30. Claiborne P, Mallios A, Taubman K. Endovascular repair of thoracic aortic injury after spinal instrumentation. Journal of Vascular Surgery Cases. 2015;1(4):264-7.

31. Xu R, Ebraheim NA, Ou Y, Yeasting RA. Anatomic considerations of pedicle screw placement in the thoracic spine. Roy-Camille technique versus open-lamina technique. Spine (Phila Pa 1976). 1998;23(9):1065-8.

32. Upendra BN, Meena D, Chowdhury B, Ahmad A, Jayaswal A. Outcome-Based Classification for Assessment of Thoracic Pedicular Screw Placement. Spine (Phila Pa 1976). 2008:33(4):384-90

33. Zdichavisky M, Blauth M, Knop C, Lotz J, Kretteck C, Bastian L. Accuracy of Pedicle Screw Placement in Thoracic Spine Fractures. Eur J Trauma. 2004;30:241-7.

34. Wang B, Lu G, Chen R, Kang Y, Li J, Chen F, et al. Accuracy of free-handed thoracic pedicle screw placement in severe idiopatic scoliosis via CT scan. Zhong Nan Da Xue Xue Bao Yi Xue Ban. 2009;34(3):226-9.

35. Min HK, Na S, Jang J. Accuracy of thoracic pedicle screw placement using freehand technique and triggered EMG in adolescent idiopathic scoliosis: Is it different between concave and convex side? J Orthop Surg (Hong Kong). 2018;26(2):1-6.

36. Kwan MK, Chiu C, Chan C, Zamani R, Hansen-Algenstaedt N. The use of fluoroscopic guided percutaneous pedicle screws in the upper thoracic spine (T1-T6): Is it safe? J Orthop Surg (Hong Kong). 2017;25(2):1-8. 